\title{
Determination of Water Requirement and Response of Wheat Varieties to Different Number of Irrigations
}

\author{
Shaloo*, R. Kaur and Man Singh
}

ICAR-Indian Agricultural Research Institute, New Delhi, India

*Corresponding author

\begin{tabular}{l} 
Key w o r d s \\
Wheat, SMD, \\
Water requirement, \\
Water Applied and \\
WUE \\
\hline Article Info \\
\hline $\begin{array}{l}\text { Accepted: } \\
12 \text { October } 2020 \\
\text { Available Online: } \\
\text { 10 February } 2021\end{array}$ \\
\hline
\end{tabular}

Keywords

Wheat, SMD,

Water requirement, Water Applied and Article Info

Accepted: Available Online: 10 February 2021
An experiment was conducted to determine water requirement and response of wheat varietiesHD-2894 and HD-2967to irrigation at 50\% soil moisture depletion (SMD) level. Moisture contents for irrigation were recorded from a root zone of $90 \mathrm{~cm}$ (from five depths viz., $0-15,15-30,30-45,45-60$ and $60-90 \mathrm{~cm}$ ). Data on meteorological parameters like temperature and rainfall were also recorded. The results indicated thatyield was significantly affected by no. of irrigations as well as varieties. Both the varieties gave significant response up to three irrigations (I3) only. The total amount of water applied up to three irrigation was $27.5 \mathrm{~cm}$. The yield obtained at irrigation level (I3) for variety HD-2894 and HD-2967 is 4.4t/ha and $6.0 \mathrm{t} / \mathrm{ha}$ and the water use efficiency (WUE) was $161.4 \mathrm{~kg} / \mathrm{ha} . \mathrm{cm}$ and $217.8 \mathrm{~kg} / \mathrm{ha} . \mathrm{cm}$, respectively.

\section{Introduction}

India is an agriculture country and wheat (Triticum aestivum L.) is the second most important cereal crop after rice. Due to climate change water shortage in the country demands to develop new technologies and methods of irrigation that can be helpful to utilize this precious input in an effective way. Temperature is one of the important weather parameters influencing the phenology and yield of wheat crop (Bishnoi et al., 1995). Mahamed et al., (2011) reported that the treatment (50\% of SMD) was superior to the $60 \%$ of SMD and $75 \%$ of SMD irrigation levels and produced the greatest plant height, dry matter, yield and yield components at each growth stage. Balasubramaniyan and Palaniappan (2001) found that water requirement of wheat varies from 180 to 420 mm. Ali et al., (2012) observed that increasing irrigation levels would improve crop growth and thus enable crop to intercept more photosynthetic radiation leading to more biological and grain yield. Molden and Oweis (2007) reported that the current focus on water productivity has evolved to include the benefits and costs of water used for agriculture in terrestrial and aquatic ecosystems. Mushari (2008)investigated that 
appreciable grain yield of barley and faba bean seed can be achieved if irrigated at $15 \%$ soil moisture depletion. Winter wheat is the largest consumer of irrigation water, improvement strategies for high WUE aiming at wheat crops are in urgent need (Xu-rong et al., 2013). Shirazi et al., (2014) reported that Irrigation regimes have significant effect on yield and growth parameters of wheat. Favorable soil moisture was maintained in the irrigation scheduling treatments of(I3) crown root initiation+ tillering+ flowering+ milking stage (Bathre et al., 2019).Knowledge of precise amount of water required by different crop in a given climatic condition of a region will be helpful in planning of irrigation scheme, irrigation scheduling and management of irrigation system. There is need to save irrigation water by providing minimum no. of irrigations without affecting yield by carrying out practices of irrigation water management to achieve higher water use efficiency (WUE). Therefore, keeping this in view, the present study was conducted to determine water requirement and response of wheat varieties to different no. of irrigations.

\section{Materials and Methods}

\section{Experimental details}

A field experiment was conducted to determining the water requirement of two wheat varieties viz. HD-2894 andHD-2967 during rabi season of 2013-14in a sandy loam soil at research farm of Water Technology Centre, IARI, New Delhi. Irrigation treatment consists of (I1-one irrigation), (I2-two irrigations), (I3-three irrigations), (I4-four irrigations) and (I5-five irrigations) based on $50 \%$ soil moisture depletion (SMD)which were arranged in split plot design with four replications. The amount of water applied to each treatment was calculated on the basis of the soil moisture contents at the time of irrigation. SMD was determined by estimating soil moisture content. For this purpose, soil samples were taken from the effective root-zone of the wheat plant which is $0-90 \mathrm{~cm}$. The root-zone was divided into five sections viz., $0-15,15-30,30-45,45-60$ and $60-90 \mathrm{~cm}$.

Soil samples were collected from these five sections with the help of a sampling tube. The fresh weight of the soil sampled was immediately recorded with the help of a portable weighing balance. After weighing, the samples were stored in tin pans which were then placed in an electric oven for $24 \mathrm{~h}$ at $100^{\circ} \mathrm{C}$ and dry weight of the samples were then recorded. Soil moisture contents were then calculated as under

Soil moisture content $(\mathrm{g})=\frac{\text { Dry weight of the sample }}{\text { Fresh weight of the sample }} \otimes 100$

The amount of water applied to each treatment was calculated on the basis of the soil moisture contents at the time of irrigation by using the following expression.

$\mathrm{d}=$ M. C $\times$ B. D $\times$ D

Where,

$\mathrm{d}=$ depth of water to be applied

M.C = moisture content $(\%)$

B.D. = bulk density of the soil

$\mathrm{D}=$ depth of root-zone to be irrigated

Water use efficiency was also calculated as the ratio of grain yield and water applied. Data on meteorological parameters like temperature and rainfall were also recorded during the period.

\section{Statistical analysis}

The data were statistically analysed for different no of irrigations and yield with the help of OPSTAT software (Sheoran et al., 1998) for estimation of analysis of variance (ANOVA) at a probability level of 0.05 . 


\section{Results and Discussion}

Total water applied during the growing period, WUE and grain yield of IARI wheat varieties are presented in Table. 1 and effect of varying levels of irrigation on grain yield is shown in Table.2. The result showed that yield was significantly affected by no. of irrigations as well as varieties. The interactive effect of variety and no. of irrigation was also found significant. Both the varieties gave significant response up to three irrigations (I3) only.

Table.1 Total water applied during the growing period, WUE and grain yield of IARI wheat varieties HD-2894(V1) and HD-2967(V2)

\begin{tabular}{|l|l|l|l|l|l|l|l|}
\hline $\begin{array}{l}\text { Grain } \\
\text { Yield(q/ha) }\end{array}$ & $\begin{array}{l}\text { water } \\
\text { applied(cm) }\end{array}$ & ER (cm) & $\begin{array}{l}\text { Total water } \\
\text { applied(cm) }\end{array}$ & \multicolumn{2}{|l|}{ WUE(kg/ha.cm) } & $\begin{array}{l}\text { No. of } \\
\text { Irrigations }\end{array}$ \\
\hline (V1) & (V2) & & & & (V1) & (V2) & \\
\hline $\mathbf{3 5 . 1}$ & 37.6 & 9.5 & 5.7 & 15.2 & 230.6 & 246.7 & I1 \\
\hline $\mathbf{3 6 . 8}$ & 39.4 & 14.8 & 5.7 & 20.5 & 179.2 & 191.5 & I2 \\
\hline $\mathbf{4 4 . 4}$ & 60.0 & 21.8 & 5.7 & 27.5 & 161.4 & 217.8 & I3 \\
\hline $\mathbf{4 5 . 3}$ & 63.2 & 28.8 & 5.7 & 34.5 & 131.2 & 183.0 & I4 \\
\hline $\mathbf{4 5 . 8}$ & 60.3 & 35.8 & 5.7 & 41.5 & 110.3 & 145.1 & I5 \\
\hline
\end{tabular}

Table.2 Effect of varying levels of Irrigation on grain yield (qt/ha) on IARI wheat varieties at $50 \% \mathrm{SMD}$

\begin{tabular}{|l|l|l|l|l|l|l|}
\hline & I1 & I2 & I3 & I4 & I5 & Mean V \\
\hline $\begin{array}{l}\text { V1 } \\
\text { (HD-2894) }\end{array}$ & 35.2 & 36.8 & 44.4 & 45.3 & 45.8 & 41.5 \\
\hline $\begin{array}{l}\text { V2 } \\
\text { (HD-2967) }\end{array}$ & 37.6 & 39.4 & 60.0 & 63.2 & 60.3 & 52.1 \\
\hline Mean I & 36.4 & 38.1 & 52.2 & 54.3 & 53.1 & \\
\hline Factors & & & C.D. at 5\% & SE(d) & SE(m) \\
\hline Factor(V) & & & 8.15 & 2.47 & 1.75 \\
\hline Factor(I) & & & 5.36 & 2.58 & 1.83 \\
\hline Factor(I)at same level of V & & 9.21 & 3.65 & 3.91 \\
\hline Factor(V)at same level of I & & 10.33 & 0.00 & 0.00 \\
\hline
\end{tabular}

Fig.1 Water production function for wheat varieties HD-2894 and HD-2967
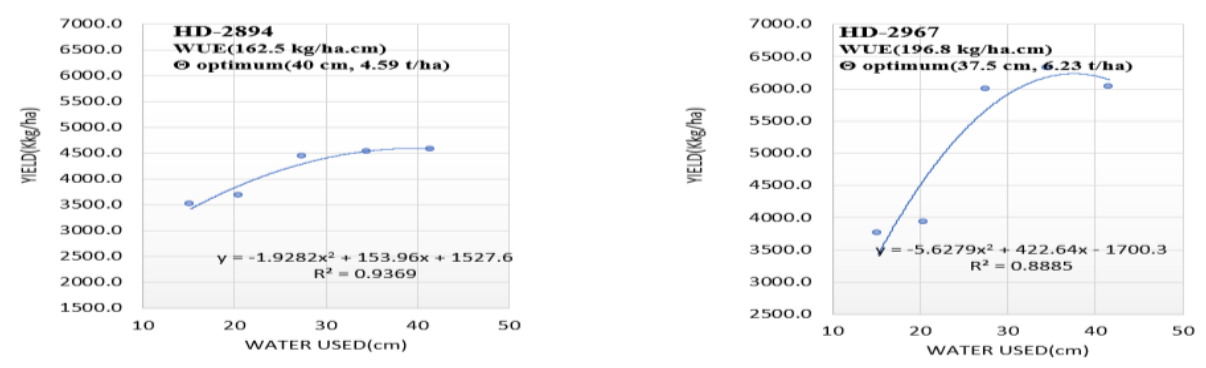
The total amount of water applied up to three irrigation was $27.5 \mathrm{~cm}$ including pre-sowing irrigation and the corresponding yield was4.4 t/ha and 6.0 t/ha for variety HD-2894 and HD-2967, respectively. The water use efficiency for varieties HD-2894 and HD2967 is $161 \mathrm{~kg} / \mathrm{ha} . \mathrm{cm}$ and $217 \mathrm{~kg} / \mathrm{ha} . \mathrm{cm}$, respectively. The optimum water requirement for both of the varieties is only three irrigations including rainfall in which highest yield was obtained. Mahmood and Ahmad (2005) determined water requirement and response of some wheat cultivars to irrigation at $50 \%$ and $70 \%$ SMD levels and found that grain yield, harvest index and water use efficiency were greater when irrigation was applied at 50\% SMD. The water production function for both the varieties is shown in Fig.1.

In conclusion the present study, water requirement of two wheat varieties was estimated and it was observed that yield was significantly affected by no. of irrigations as well as varieties. Both the varieties gave significant response up to three irrigations (I3) only. This type of study can be useful for precise irrigation in wheat crop where farmers will supply the required amount of water and reduce wastage of water.

\section{References}

Naeem Mahmood and Rai Niaz Ahmad. 2005. Determination of Water Requirements and Response of Wheat to Irrigation at Different Soil Moisture Depletion Levels, Int. J. Agri. Biol, Vol.7(5):812-815.

Bishnoi, O.P., Singh, S. and Niwas, R. 1995. Effect of temperature on phenological development of wheat (Triticum aestivum L.) crop in different row orientation. Indian J.Agric.Sci., 65: 211214.

Sheoran, O.P, Tonk, D.S, Kaushik, L.S,
Hasija, R.C. and Pannu, R.S. 1998. Statistical software package for agricultural research workers. Recent advances in information theory, statistics \& computer applications by D.S. Hooda\&R.C.Hasija Department of mathematics statistics, CCS HAU, Hisar (139-143).

Ali, H., Tariq, N., Ahmad, S., Rasheed, M., Chattha, T.H. andHussain, A. 2012. Growth and radiation use efficiencyof wheat as affected by different irrigation levels andphosphorus application methods. J. Anim. Plant Sci.,22(4): 1118-1125.

Mushari A. Al-Naeem. 2008. Effect of Irrigation Scheduling on Growth Parameters and Water Use Efficiency of Barely and Faba Bean Crops in AlAhsa, Saudi Arabia. American Journal of Plant Physiology, 3: 111-120.

Balasubramaniyan, P. and S.P. Palaniappan. 2001. Principles and Practicesof Agronomy. Agrobios, Jodhpur, India.

Mahamed Badel Mahamed, Ed Sarobol, Tilahun Hordofa,SudsaisinKaewrueng and Jindarath Verawudh. 2011. Effects of Soil Moisture Depletion at Different Growth Stages on Yield and Water Use Efficiency of Bread Wheat Grown in Semi-Arid Conditions in Ethiopia. Kasetsart J. (Nat. Sci.) 45: $201-208$

MEI Xu-rong, ZHONG Xiu-li, Vadez Vincent and LIU Xiao-ying. 2013. Improving Water Use Efficiency of Wheat Crop Varieties in the North China Plain: Review and Analysis. Journal of Integrative Agriculture, 12(7): 12431250

Shirazi, S. M., ZulkifliYusop, N. H. Zardari and Z. Ismail. 2014. Effect of Irrigation Regimes and Nitrogen Levels on the Growth and Yield of Wheat. Advances in Agriculture. 2014, 6 pages http://dx.doi.org/10.1155/2014/250874

Bathre S, Nema R.K., Bhan M. and Tiwari 
Y.K. 2019. Study of Soil Moisture Depletion Pattern of Wheat with Different Irrigation Schedule. International Journal of Microbiology
Research, ISSN: 0975-5276 \& E-ISSN: 0975-9174, Volume 11, Issue 6, pp.1613-1619.

\section{How to cite this article:}

Shaloo, R. Kaur and Man Singh. 2021. Determination of Water Requirement and Response of Wheat Varieties to Different Number of Irrigations. Int.J.Curr.Microbiol.App.Sci. 10(02): 210214. doi: https://doi.org/10.20546/ijcmas.2021.1002.026 